\title{
Victor A. Beker
}

University of Belgrano and University of Buenos Aires

Department: Economics - Argentina

e-mail: victor.beker@ub.edu.ar

\section{THE EUROPEAN DEBT CRISIS: CAUSES AND CONSEQUENCES}

JEL classification: E6, F3, G01

\begin{abstract}
A common explanation for the European debt crisis has been that the introduction of the euro in 2001 caused interest rates to fall in those countries where expectations of high inflation previously kept interest rates high. Bond buyers assumed that a bond issued by any government in the European Monetary Union was equally safe. As a result, the interest rates on Greek, Italian, etc. government bonds were not significantly different from the interest rate on the German government bonds. Governments responded to the low interest rates by increasing their borrowing. However, data do not endorse this explanation, as is shown in the paper. An alternative explanation has been that the European debt crisis was just a consequence of the American subprime one. Again, data do not entirely support this hypothesis although the connection between both crises is explored in the paper. A third argument states that the introduction of the euro, and its effects on external competitiveness, triggered mounting disequilibria and debt accumulation in the noncore countries or periphery. This argument seems to be valid to a certain extent just in the cases of Greece and Portugal, but not for the rest of the countries involved in the crisis where other factors seem to have played a major role. A distinction is made between a first group of countries whose debt problems have roots before 2007 but did not worsen significantly after that year and a second one of "new" highly indebted countries. Finally, Spain appears as a special case. The development of the indebtedness process in these three different types of countries allows isolating the factors which were determinant in each case. The conclusion is that the European indebtedness process does not accept a unique explanation and its solution will necessarily require resource transfers from the richer to the poorer countries of the euro-zone.
\end{abstract}

Keywords: sovereign-debt crisis, euro-zone, budget deficit. 


\section{INTRODUCTION}

In late 2009, the then recently appointed Greek Prime Minister George Papandreou announced that previous governments had failed to reveal the true size of the nation's deficits. Greece's debts were larger than had been reported. ${ }^{1}$ After that, the Portuguese, Spanish and Italian public debts also became a matter of concern because their government debt/GDP ratios were near to the Greek one. The European sovereign debt crisis had started.

This paper is organized as follows. Section 2 analyzes the origin of the crisis in these European countries. In Section 3, the specificities of euro debt are discussed. Section 4 analyzes the case of Ireland whose debt crisis preceded the Greek one. Section 5 is devoted to the latter. The role of a single currency on regional imbalances is underlined in Section 6. The case of Spain is analyzed in Sections 7 and 8. Section 9 is devoted to the analysis of the Italian case. Section 10 summarizes the findings of the paper and concludes.

\section{EVOLUTION OF COUNTRIES` INDEBTEDNESS}

A first question has to do with the origin of the European debt crisis. Some people have pointed their fingers at the American financial crisis. "This crisis was not originated in Europe," claimed the EU Commission President Jose M. Barroso, who added: "This crisis originated in North America and much of our financial sector was contaminated by... unorthodox practices from some sectors of the financial market."2

However, as we shall see, Greece and Italy were already heavily indebted as early as 1996, long before the US financial crisis blew up. However, this does not exclude the possibility of some connection between both crises, which is explored below by comparing the debt situation before and after 2007 .

A second question is how the debtor country governments as the Greek one became so highly indebted. A common explanation for this has been the following. ${ }^{3}$

Banks in Germany, France and elsewhere had bought and exposed themselves massively to Greek debt because they assumed that Greek debt, like other euro-area public debt, was essentially risk-free.

Because the monetary union made the commitment to low inflation more credible, the introduction of the euro in 2001 caused interest rates to fall in those countries where expectations of high inflation previously kept interest rates high.

Bond buyers assumed that a bond issued by any government in the European Monetary Union was equally safe. As a result, the interest rates on Greek and Italian government bonds were not significantly different from the interest rate on German

\footnotetext{
${ }^{1}$ In fact, in 2004, Eurostat had already revealed that the statistics for the budget deficit had been under-reported at the time Greece was accepted into the European Monetary Union in 2000. According to Eurostat, the 1999 deficit was 3.4\% of GDP instead of the originally reported $1.8 \%$.

${ }^{2}$ The Week. June 20, 2012. http://theweek.com/article/index/229570/did-the-us-causethe-european-debt-crisis.
}

${ }^{3}$ See, for example, Feldstein (2012). 
government bonds. Governments responded to these low interest rates by increasing their borrowing.

However, the data do not endorse the former explanation. Table 1 shows the general government debt/GDP ratio in 2010 for those countries whose public debt ratio exceeded the average for the 27 EU countries as a whole. France and Germany are among the more than average indebted countries, which shows that high indebtedness is not solely a southern country phenomenon.

Table 1

\section{General government gross debt}

(Percentage of GDP) - 2010

\begin{tabular}{|l|l|}
\hline Country & $\mathbf{2 0 1 0}$ \\
\hline EU (27 countries) & 80.1 \\
\hline Greece & 144.9 \\
\hline Italy & 118.4 \\
\hline Belgium & 96.2 \\
\hline Portugal & 93.3 \\
\hline Iceland & 92.9 \\
\hline Ireland & 92.5 \\
\hline Germany & 83.2 \\
\hline France & 82.3 \\
\hline Hungary & 81.3 \\
\hline
\end{tabular}

Source: Eurostat

Table 2 shows the evolution of government debt between 1996 and 2010 for a selected group of countries. First, it can be noted that some of the now highly indebted countries did not exceed the Maastricht limit of $60 \%$ of GDP until as recently as 2007.

Table 2

\section{Evolution of general government gross debt}

(Percentage of GDP) - 1996/2010

\begin{tabular}{|l|l|l|l|l|l|}
\hline Country & \multicolumn{1}{|c|}{$\mathbf{2 0 0 7}$} & \multicolumn{1}{|c|}{$\mathbf{2 0 0 8}$} & \multicolumn{1}{|c|}{$\mathbf{2 0 0 9}$} & \multicolumn{1}{|c|}{$\mathbf{2 0 1 0}$} & \multicolumn{1}{|c|}{$\mathbf{2 0 1 0 / 0 7}$} \\
\hline EU (27 countries) & 59.00 & 62.5 & 74.7 & 80.1 & 35.76 \\
\hline Ireland & 24.8 & 44.2 & 65.2 & 92.5 & 272.98 \\
\hline Iceland & 28.5 & 70.3 & 87.9 & 92.9 & 225.96 \\
\hline Romania & 12.8 & 13.4 & 23.6 & 31.0 & 142.19 \\
\hline UK & 44.4 & 54.8 & 69.6 & 79.9 & 79.95 \\
\hline
\end{tabular}




\begin{tabular}{|l|l|l|l|l|l|}
\hline Spain & 36.2 & 40.1 & 53.8 & 61.0 & 68.51 \\
\hline Portugal & 68.3 & 71.6 & 83.0 & 93.3 & 36.60 \\
\hline Greece & 107.4 & 113.0 & 129.3 & 144.9 & 34.92 \\
\hline Hungary & 67.0 & 72.9 & 79.7 & 81.3 & 21.34 \\
\hline Italy & 103.1 & 105.8 & 115.5 & 118.4 & 14.84 \\
\hline Belgium & 84.1 & 89.3 & 95.9 & 96.2 & 14.39 \\
\hline
\end{tabular}

Source: Eurostat

Second, the public debt to GDP ratios of Greece, Ireland, Belgium, Spain and Italy were almost the same in 2007 as they were in 2001 (in some cases, they were even lower). This contradicts the idea that it was the introduction of the euro and the consequent fall in interest rates that stimulated governments to substantially increase their borrowing.

On the other hand, Greece, Italy, Portugal, Belgium and Hungary had already exceeded the $60 \%$ Maastricht limit in $2007,{ }^{4}$ when the American subprime crisis started. However, they shared the slowest increasing government debt/GDP ratios between 2007 and 2010. Even more, by 1996 - before the introduction of the euro- Italy, Greece and Belgium were already highly indebted countries.

Therefore, we can distinguish a first group of countries whose debt problems have roots before 2007 and did not worsen significantly after that year: Greece, Italy, Portugal, Belgium and Hungary. Moreover, by 2001 Greece's public debt/GDP ratio was already 103.7 compared with 108.2 for Italy and 106.5 for Belgium. This last country is a special case because it is the only one in the group that reduced its debt between 2001 and 2007.

A second group is formed by those "new" highly indebted countries: Ireland and Iceland. They showed the highest rates of increase in their public debt to GDP ratios between 2007 and 2010 and their 2010 ratios were above the average for the EU. Romania also had a fast growing ratio but the level of public debt attained in 2010 as a percentage of GDP was still far below the average for the EU.

The United Kingdom comes immediately below these countries with a debt to GDP ratio practically equivalent to the EU average. Finally, we have Spain, whose government debt to GDP ratio was in 2010 only a bit above the Maastricht limit and had increased at a lower rate than the UK's ratio between 2007 and 2010. However, while the UK's debt was considered to be safe, Spain's debt was no better rated than those of Portugal or Italy.

Thus, there are different cases to consider rather than a single story for European countries' indebtedness process. The idea that we may have a unique explanation for the debt crisis is also presented in Perez-Caldentey and Vernengo (2012, 3 ), who argue that "the crisis in Europe is the result of an imbalance between core and noncore countries that is inherent in the euro economic model." They also maintain that it was the euro, and its effects on external competitiveness, that triggered mounting

\footnotetext{
${ }^{4}$ As Hungary is not a member of the euro-zone, the Maastricht criteria was not mandatory for it.
} 
disequilibria and debt accumulation in noncore countries or peripheries. As we will see, this argument seems to be valid to a certain extent just in the cases of Greece and Portugal, but not for the rest of the countries involved in the crisis where other factors seem to have played a major role.

In what follows, we concentrate our analysis on the five euro-area countries in the eye of the debt crisis storm with a casual reference to the case of Iceland. ${ }^{5}$

\section{SPECIFICITIES OF THE EURO-AREA PUBLIC DEBT}

A first peculiarity of the euro-area public debt is that, strictly speaking, it is neither purely domestic nor purely external. Most of the public debt issued by euro-area countries is denominated in euro and is mostly held by euro-area residents. Yet, it is different from the domestic debt of countries owning their own currencies because more of it is held outside the issuing country and because the issuing country does not have full control over the currency in which the debt is denominated. Therefore, debt in the euro-area can be considered to be both 'foreign' and 'domestic' (Gianviti et al., 2010, $18)$.

This means that euro-area public debt is not subject to the currency mismatch associated with external debt: governments have to pay their debts in the same currency they collect their revenues. However, it also means that a national government cannot revert to high inflation to rid itself of an excessive debt burden, as might be the case if the debt were strictly domestic.

The European Monetary Union seems to assume that sovereign debt crises cannot happen. At least, it has no provision for them. Moreover, the common reading of Article 125 of the Lisbon Treaty has been that it rules out the possibility of a bailout of an EU member state by other member states or by the EU. Therefore, without these inflation and bailout channels, a country with a situation of excessive debt has only two ways out of it: severe and harmful fiscal retrenchment or default.

\section{THE NEW HIGHLY INDEBTED COUNTRIES: THE CASE OF IRELAND}

Ireland's economy had by 2007 already become dangerously dependent on construction and housing as a source of economic growth and tax revenue. A lightly regulated financial system fed on this process. In fact, the growing construction boom was fuelled by the increasing reliance of Irish banks on wholesale external borrowing at a time when international financial markets were awash with cheap investable funds. The fact that Ireland was a founder member of the euro-zone brought a dramatic and sustained fall in nominal and real interest rates that stimulated the protracted building boom. Specific tax incentives boosted the overheated construction sector. From late 2003 onwards, banks stimulated demand with financial innovations such as $100 \%$ loanto-value mortgages.

When the global economic environment changed at the beginning of 2007, Irish residential property prices started falling and kept falling during the rest of 2007 and

\footnotetext{
${ }^{5}$ The Cyprus banking crisis is an especial case, mainly the result of the Greek sovereign debt haircut, although it has Something in common with Iceland's case.
} 
2008. Heavy loan losses on the development property portfolios acquired at the peak of the market became inevitable. The decline in property prices and the collapse in construction activity resulted in severe losses in the Irish banking system. The story is not very different from the one that led to the US subprime crisis. "In their anxiety to protect market share against the competitive inroads of Anglo Irish Bank and UK-based retail lenders, their (Irish) banks' management tolerated a gradual lowering of lending standards, including decisions to authorize numerous exceptions to stated policies." (Governor of the Central Bank of Ireland, 2010, 8). This was tolerated by an unduly deferential approach to the banking industry by regulators. Outside bodies such as the IMF and OECD never drew attention to the threats that lay ahead.

Although banks carried out a quantification of risks in the context of the stress test exercises reported annually to the regulatory authority, "the capacity of the banks to undertake the exercise differed greatly; indeed none of them had reliable models, tested and calibrated on Irish data, which could credibly predict loan losses under varying scenarios" (Ibid., 11).

While at the end of 2003, the net indebtedness of Irish banks to the rest of the world was just $10 \%$ of GDP, by early 2008 borrowing, mainly for property, had jumped to over $60 \%$ of GDP. By early 2008, Irish banks found it more difficult to maintain funding in the international wholesale markets and, at the same time, there was a more rapid pull back by domestic investors from the property market.

Two weeks after Lehman Brothers announced it would file for Chapter 11 bankruptcy protection, the provision of a blanket system-wide state guarantee for Irish banks was announced. This measure was taken because of the drain of liquidity that had been affecting all Irish banks and that had brought one important bank to the point of failure.

Government spending doubled in real terms between 1995 and 2007, rising at an annual average rate of $6 \%$. With the economy growing at an even faster rate, this implied a generally falling or stable expenditure ratio of expenditure to GDP until 2003. However, thereafter the ratio rose, especially after output growth began to slow in 2007 and the collapse in tax revenues in 2008-09. Much of the reason for the revenue collapse lies in the systematic shift over the previous two decades away from stable and reliable sources such as personal income tax, VAT and excises towards cyclically sensitive taxes as corporation tax, stamp duties and capital gains tax.

In April 2009, the Irish government established the National Asset Management Agency (NAMA), with the mandate to purchase the universe of development-related loans (above a certain value) from banks. This category of loans was the main source of uncertainty concerning total loan losses. During 2009-10, NAMA purchased most of these loans at a steep average discount, but this meant that banks required substantial upfront recapitalization programs, which could only be provided by the state. These higher capitalization costs led to a sharp increase in gross government debt. Extra capital requirements by the banking system in 2009 and 2010 contributed to increased market concerns about the sustainability of the fiscal position. In fact, the deficit, as measured by the general government balance, widened from balance in 2007 to $7.3 \%$ of GDP in 2008 and to $14.1 \%$ in 2009 , before it increased to $31.2 \%$ of GDP in 2010 due to the substantial government support to Irish banks. Excluding support to the banking system, the deficit was $11.5 \%$ of GDP in 2009 and $10.9 \%$ of GDP in 2010. The public funds aimed at rescuing the Irish banking sector represented $12.5 \%$ of Ireland's GDP. As shown in Table 2, Irish public debt soared from 24.8\% of GDP in 2007 to $92.5 \%$ in 
2010. Finally, the Irish government had to request assistance from the EU and IMF in November 2010 to avoid default on its public debt.

\section{THE “OLD” INDEBTED COUNTRIES: THE CASE OF GREECE}

As stated before, Greece did not comply with the Maastricht criterion with respect to the budget deficit at the time it joined the euro-zone in 2001. "Creative" statistics allowed it to be admitted into what has been conceived as a very exclusive club. Its debt/GDP ratio was already 103.7 in 2001, far above the 60\% Maastricht criterion. ${ }^{6}$ However, it declined to 97.4 in 2003. From then on, it kept increasing until reaching 144.9 in 2010. This reflected the increasing budget deficit Greece's public accounts had shown since 2000 (Table 3).

Table 3

\section{General government expenditure, revenue and deficit}

2000/11

(Percentage of GDP)

\begin{tabular}{|c|c|c|c|}
\hline Year & Expenditure & Revenue & Balance \\
\hline 2000 & 46.7 & 43.0 & -3.7 \\
\hline 2001 & 45.3 & 40.9 & -4.4 \\
\hline 2002 & 45.1 & 40.3 & -4.8 \\
\hline 2003 & 44.7 & 39.0 & -5.7 \\
\hline 2004 & 45.5 & 38.1 & -7.4 \\
\hline 2005 & 44.6 & 39.0 & -5.6 \\
\hline 2006 & 45.2 & 39.2 & -6.0 \\
\hline 2007 & 47.6 & 40.8 & -6.8 \\
\hline 2008 & 50.6 & 40.7 & -9.9 \\
\hline 2009 & 53.8 & 38.2 & -15.6 \\
\hline 2010 & 50.2 & 39.7 & -10.5 \\
\hline 2011 & 50.1 & 40.9 & -9.2 \\
\hline
\end{tabular}

Source: Eurostat

\footnotetext{
${ }^{6}$ Notwithstanding its noncompliance with the Maastricht debt standard, Greece was admitted with the argument that it was expected to be making progress over time towards that goal.
} 
Entrance into the euro-zone meant that Greece -as the other members of the euro-zone- gave up one of the tools a country has to reduce its budget deficit: devaluation. In fact, in equilibrium:

$\left(\mathrm{I}_{\mathrm{d}}-\mathrm{S}\right)+(\mathrm{G}-\mathrm{T})=\mathrm{M}-\mathrm{X}$

where $I_{d}$ is domestic investment, $S$ is national saving, $G$ is government expenditure, $T$ is government revenue and $(\mathrm{M}-\mathrm{X})$ stands for current account balance. A devaluation will reduce the value of $(\mathrm{M}-\mathrm{X})$; if the domestic private balance does not change, the government balance will be reduced. ${ }^{7}$ The most direct way to do this is by taxing exports, as Argentina did in 2002, where export taxes absorbed a good part of the devaluation effect on exportable domestic prices.

As a matter of fact, Georgantopoulos and Tsamis $(2011,161)$ find for Greece, during the period 1980-2009, a significant unidirectional causal relationship between exchange rates and budget deficit running from the nominal effective exchange rate to the budget deficit. Moreover, they concluded that "a significant part of budget deficits' variance is caused by exchange rates since with a seven period lag $61.89 \%$ of [the budget deficit] is explained by [the nominal effective exchange rate] and by the end of the ten-year lag $83.97 \%$ of budget deficits' variance is caused by nominal effective exchange rates."

The continuous revaluation of the euro worsened Greece's budget imbalance after 2000. Figure 1 illustrates the relationship between the euro/dollar rate of exchange and the one-year lagged budget deficit/GDP ratio between 2000 and 2011. This runs in the same direction as the relationship found by Georgantopoulos and Tsamis. However, in his analysis of the European crisis, Lapavitsas $(2012,4)$ does not pay attention to this factor and only mentions that peripheral countries joined the euro at generally high rates of exchange with the purpose of controlling inflation.

\footnotetext{
${ }^{7}$ The opposite happens, of course, in the case of a revaluation of the local currency.
} 


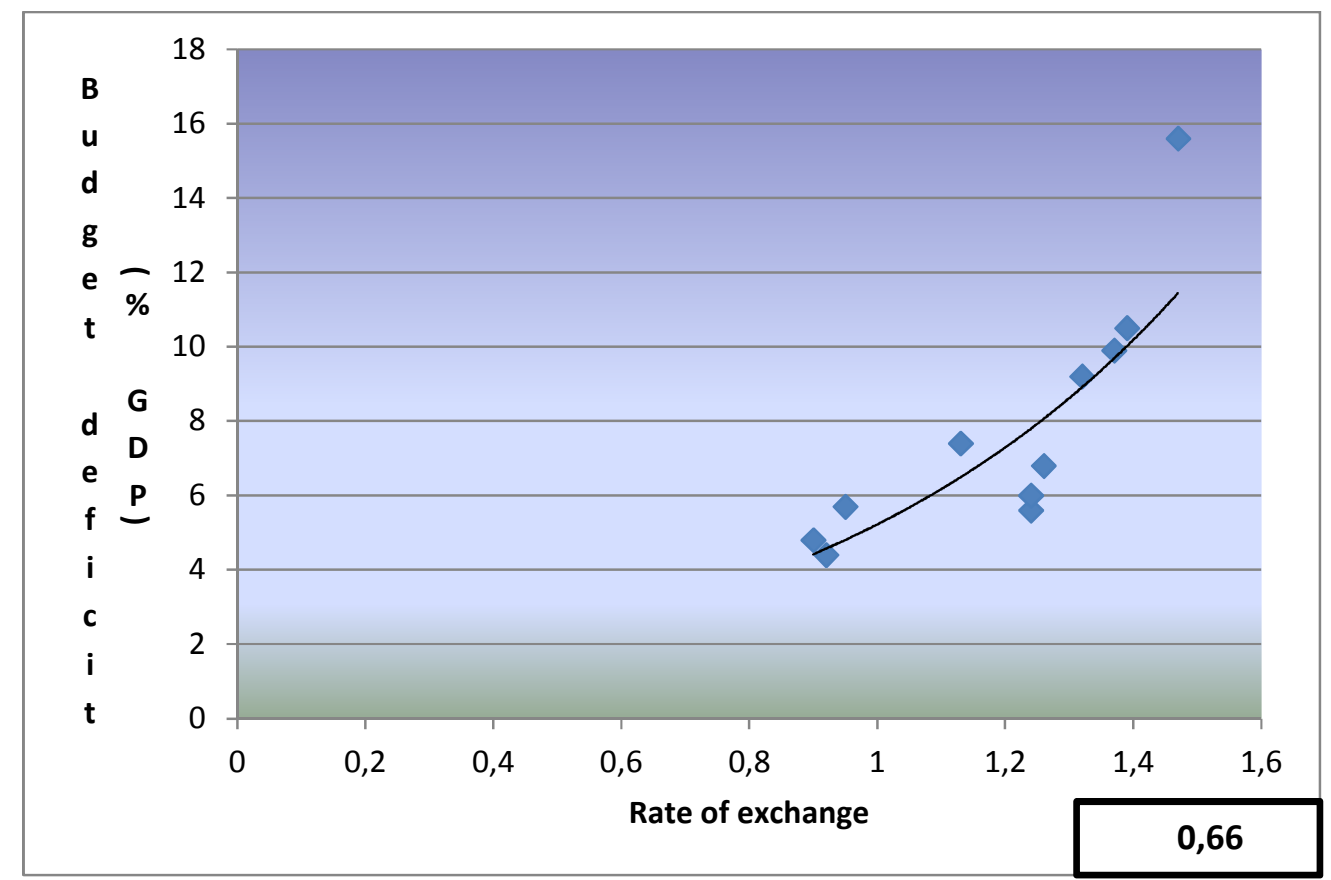

Figure 1.Budget deficit and euro rate of exchange. 2000-2011

What is the explanation for this positive association between the rate of exchange and budget imbalance? The appreciation of the euro ${ }^{8}$ resulted in a loss of external competitiveness in the Greek economy, which led to a persistent deficit in the current account (Figure 2). An appreciation of the real exchange rate increases the purchasing power of domestic incomes in terms of imported goods. More imports and fewer exports result in a slowdown in economic activity. Tax revenues decline, while the government feels compelled to keep or increase public expenditure to make up for the decline in private demand. The budget deficit increases and so does public debt. Increasing demand for funds by the public sector leads to an increase in interest rates, which depresses again economic activity. According to the figures in Table 3, public revenues have declined since Greece joined the euro-zone; since 2007, public expenditure increased, accelerating the rise in the budget deficit.

${ }^{8}$ The exchange rate between dollar and euro was, in October 2000, $0.85 \$ / €$ and reached in April 2008, 1.60 \$/€; an appreciation of $88 \%$. 


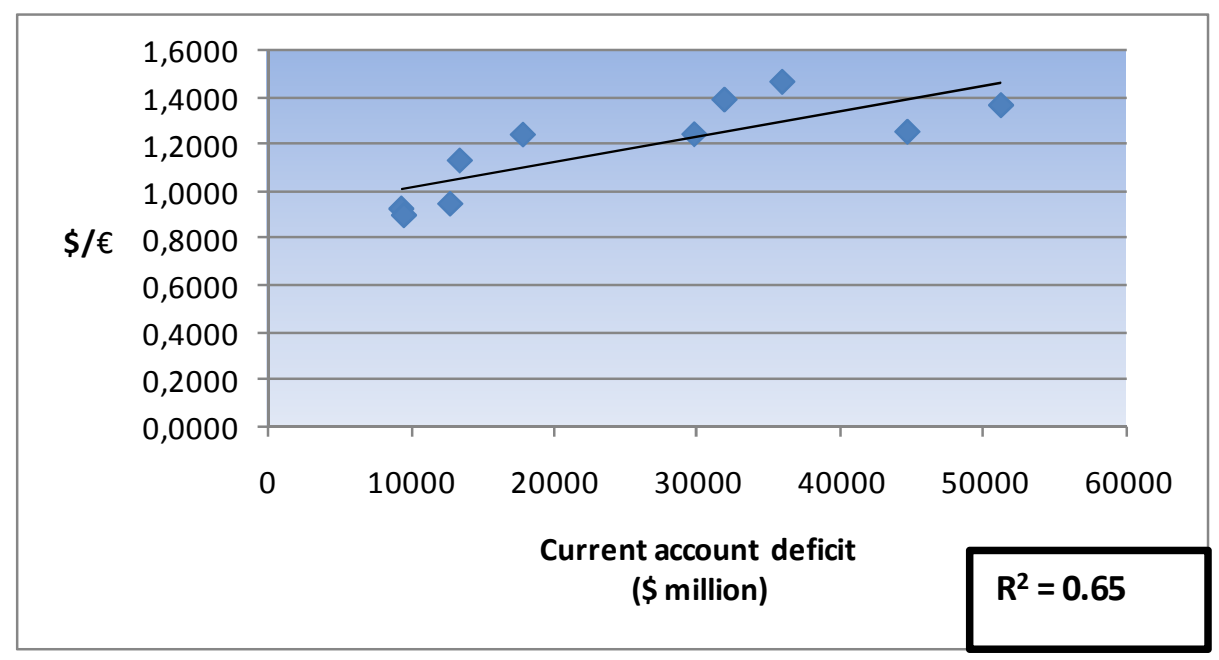

Figure 2.Current account deficit and the euro rate of exchange. 2001/11

However, in the literature related to the "twin deficits hypothesis," it has usually being argued that causality runs from the government budget deficit to the current account, not the other way around. However, empirical studies are far from conclusive: in some cases, they support the conventional hypothesis; ${ }^{9}$ others support the reverse causality running from the current account deficit to the fiscal deficit; ${ }^{10}$ some support the Ricardian equivalence that budget and trade deficits are not correlated. ${ }^{11}$ And, finally, some find both types of evidence or a bilateral relationship. ${ }^{12}$

In the case of Greece, it is clear that, since the introduction of the euro, causality cannot run from the budget deficit to the nominal rate of exchange. Moreover, when the budget deficit variable is introduced with a one-year lag.

The increasing Greek debt was primarily the result of growing budget deficits triggered by the appreciation of the euro and the consequent loss of competitiveness experienced by the Greek economy. This brings us to the issue of regional imbalances raised by Perez-Caldentey and Vernengo (2012).

\section{THE EXCHANGE RATE AND REGIONAL IMBALANCES}

The euro-area aggregate trade and current account position have always been close to balance but this only means that the euro rate of exchange is in line with the competitiveness of the core countries of the euro-zone. Many industries in Greece and other peripheral countries are not competitive at that rate of exchange; that is why these

\footnotetext{
${ }^{9}$ Abell (1990), Bachman (1992), Piersanti (2000), Leachman and Francis (2002), Cavallo (2005) and Erceg et al. (2005).

${ }^{10}$ Anoruo and Ramchander (1998), Khalid and Teo (1999) and Alkswani (2000).

${ }^{11}$ Miller and Russek (1989), Dewald and Ulan (1990), Enders and Lee (1990) and Kim (1995).

${ }^{12}$ Mukhtar et al. (2007) and Islam (1998).
} 
countries run increasing current account deficits (see Table 4). In fact, external imbalances diverge sharply in the euro-area: while Germany, the Netherlands and Finland run significant surpluses, countries in southern Europe run huge deficits.

Table 4

\section{Current account balance in selected EMU countries- 2001/10}

(Percentage of GDP)

\begin{tabular}{|c|c|c|c|c|c|}
\hline & 2001 & 2002 & 2003 & 2004 & 2005 \\
\hline France & 1.8 & 1.2 & 0.7 & 0.5 & -0.5 \\
\hline Germany & 0.0 & 2.0 & 1.9 & 4.7 & 5.1 \\
\hline Netherlands & 2.6 & 2.6 & 5.5 & 7.6 & 7.4 \\
\hline Finland & 8.4 & 8.5 & 4.8 & 6.2 & 3.4 \\
\hline Greece & -7.2 & -6.5 & -6.5 & -5.8 & -7.6 \\
\hline Italy & 0.3 & -0.4 & -0.8 & -0.3 & -0.9 \\
\hline Portugal & -10.3 & -8.2 & -6.4 & -8.3 & -10.3 \\
\hline Spain & -3.9 & -3.3 & -3.5 & -5.2 & -7.4 \\
\hline
\end{tabular}

\begin{tabular}{|c|c|c|c|c|c|}
\hline & 2006 & 2007 & 2008 & 2009 & 2010 \\
\hline France & -0.6 & -1.0 & -1.7 & -1.5 & -1.7 \\
\hline Germany & 6.3 & 7.5 & 6.3 & 5.6 & 5.7 \\
\hline Netherlands & 9.3 & 6.7 & 4.3 & 4.2 & 6.6 \\
\hline Finland & 4.2 & 4.3 & 2.6 & 1.8 & 1.4 \\
\hline Greece & -11.4 & -14.6 & -14.9 & -11.1 & -10.1 \\
\hline Italy & -1.5 & -1.3 & -2.9 & -2.0 & -3.5 \\
\hline Portugal & -10.7 & -10.1 & -12.6 & -10.9 & -10.0 \\
\hline Spain & -9.0 & -10.0 & -9.6 & -5.2 & -4.6 \\
\hline
\end{tabular}

Source: Eurostat

The euro-zone reproduces the sort of regional problems that exist within many countries. There is a highly competitive core and a relatively backward periphery. Therefore, a long-run strategy for regional convergence is needed and, at the same time, a short-run one to smooth the transition process. Although EU regional policy aims at promoting the "harmonious, balanced and sustainable development of the European Union," it has proven up to now to be insufficient to face the specific consequences of the monetary union. Therefore, the Greek government had to face the outcome of joining the euro-zone and had to take decisions that resulted in a worsening of the heavy indebtedness pre-existing at the time of joining the euro-zone.

Katsimi and Moutos (2010) emphasise the role of current of account imbalances due to the loss in Greek international competitiveness. However, productivity gaps and 
external deficits exist within each country. All American states have the same productivity? What about East and West Germany? Who cares what their external balances are? A region within a country can run a current account deficit indefinitely as long as there is a transfer of resources from the richer to the poorer regions. Therefore, this should not be a problem for the euro-zone provided those who, thanks to the eurozone, benefit of external surpluses are ready to transfer resources to the backward periphery. This is the real issue at stake as far as the productivity gap is concerned.

Germany's unification process could have been an interesting antecedent to take into consideration. The major economic implication of German economic and monetary union was precisely that East Germany would run a current account deficit with the rest of the country that was financed by transfers from the West. In the case of Germany, the New Länder began with an enormous competitive disadvantage and West Germans were supposed to transfer between $3 \%$ and $4 \%$ of GDP per annum to the East (Carlin, 1998, 16). However, no provision was taken in the euro-zone to make up for the short-run negative consequences that peripheral economies could suffer from joining the euro. ${ }^{13}$

In fact, when the monetary union was implemented in 1999, the functioning of the single currency was seen as a sort of panacea, making additional policy targeting seem superfluous. However, the result has been an increasing current account deficit for Greece and other peripheral countries. What has not been done before in the form of resource transfers from the richer to the poorer countries of the euro-zone has to be done in the way of helping these countries restructure their debts.

Somebody may argue that internal devaluation is the way through which Greek could become competitive. Downwards price and wage inflexibility makes this a very painful and unbearably long process. It did not work in Argentina, which, after three years of an ever-deepening recession/depression, had no alternative but to default and devalue its currency. It does not seem to be a valid alternative for Greece either.

\section{SPAIN: A SPECIAL CASE}

The weight of Spain's public debt as of 2011 was substantially lower than the weight of the debt of the United Kingdom and of Germany. Spain's government debt ratio was just 68.5 of GDP against 85.7 in the UK and 81.2 in Germany, not to mention 165.3 in Greece and 120.1 in Italy. Why was, then, Spain involved in the European financial crisis? There is just one single reason: because it evoked the Irish case. In 2007, the public debt to GDP ratio in Ireland was only 24.8. However, it soared to 65.2 in 2009.

As in Ireland, construction had been a fast growing industry in Spain. It expanded at a rate of 5\% per year between 1996 and 2007. Between 1998 and 2007, the number of housing units grew 30\% (Arellano and Bentolila, 2009, 28). House prices increased dramatically and people expected the process to go on without an end. Real house prices - house prices adjusted for the change in the consumer price index increased by $127 \%$ between 1996 and 2007 (André, 2010, 9). Therefore, real estate

\footnotetext{
${ }^{13}$ I refer here to the specific consequences of joining the euro, which are independent of those following the EU integration to make up for which there were significant resource transfers, particularly through structural funds.
} 
became the preferred destination for savings. Tax benefits ${ }^{14}$ stimulated even greater demand for real estate, biasing household investment to housing in place of other types of assets. This process was reinforced after 1999. After becoming a member of the eurozone, Spain benefited - as in the case of Greece and other southern Europe countries from a drastic reduction in interest rates. The flight of capital from the equity markets that occurred between 2000 and 2003 was primarily funneled to the real estate sector. Loans became available at lower interest rates. Therefore, businesses and individuals saw their borrowing capacities increase; this stimulated the demand for house building. Housing became a shelter for assets: real estate investments promised attractive capital gains. Houses were bought because prices were expected to rise and prices rose because there were more and more purchases increasingly financed by loans. The construction market flourished. Banks offered 40-year and, later, even 50-year mortgages. The construction sector increased its share of Spanish GDP from 6.9\% in 1995 to a high of $10.8 \%$ in 2006. In 2007, construction accounted for $13.3 \%$ of total employment. However, that year, coinciding with the global economic crisis, the real estate bubble burst. When international liquidity - until then cheap and plentiful - started lacking, the Spanish real estate market entered a crisis. Prices started declining in 2008.

Regional loans and savings banks, the so-called "cajas," were very active in the real estate market. They owned 56\% of the country's mortgages in 2009 . They were the first victims when the market crashed that year: debtors fell into bankruptcy and bad loans dramatically increased. In March 2009, the Spanish government announced its first bailout of a caja. After that, more bank bailouts were announced by the Spanish government. While these government bailouts kept these banks from going bankrupt, investor confidence in the Spanish economy sunk even lower. Many real estate developers avoided bankruptcy only because banks kept permitting them to refinance their loans. In this way, loans were reported as performing. In May 2012, Bankia, a bank that resulted from the merger of several cajas, had to be bailed out by the government. At that time, it was the fourth bank by size in the Spanish ranking of banking institutions.

\section{THE EVOLUTION OF PUBLIC FINANCE IN SPAIN}

Table 6 shows the evolution of general government expenditure, revenue and deficit between 2000 and 2011. It shows that Spain had a small deficit between 2000 and 2004, far below the ceiling of $3 \%$ of GDP that the European Stability and Growth Pact established for member states after the introduction of the euro on January 1, 1999. From 2005 to 2007, the increase in revenues allowed the government to run a surplus. The situation abruptly reversed in 2008 precipitated by a significant decrease in revenues, a decline that deepened in the following years, as a reflection of the international financial crisis.

\footnotetext{
${ }^{14}$ Altogether, $15 \%$ of mortgage payments are deductible from personal income taxes in Spain.
} 
Table 6

General government expenditure, revenue and balance

2000/11

(Percentage of GDP)

\begin{tabular}{|c|c|c|c|}
\hline Year & Expenditure & Revenue & Balance \\
\hline 2000 & 39.2 & 38.2 & -0.9 \\
\hline 2001 & 38.7 & 38.1 & -0.5 \\
\hline 2002 & 38.9 & 38.7 & -0.2 \\
\hline 2003 & 38.4 & 38.0 & -0.3 \\
\hline 2004 & 38.9 & 38.8 & -0.1 \\
\hline 2005 & 38.4 & 39.7 & 1.3 \\
\hline 2006 & 38.4 & 40.7 & 2.4 \\
\hline 2007 & 39.2 & 41.1 & 1.9 \\
\hline 2008 & 41.5 & 37.0 & -4.5 \\
\hline 2009 & 46.3 & 35.1 & -11.2 \\
\hline 2010 & 45.6 & 36.3 & -9.3 \\
\hline 2011 & 43.6 & 35.1 & -8.5 \\
\hline
\end{tabular}

Source: Eurostat

As can be seen in Table 7, the rate of growth plummeted in 2008 and became negative in 2009 and 2010. The contraction in international liquidity supply was followed by a restriction on credit and subsequently by a sharp decline in construction and employment. The increase in unemployment meant a rise in spending on unemployment and other social benefits. The bailout of several cajas was another source of increase in public expenditure. On the other hand, the decline in GDP was followed by a weakening of public revenues, especially those linked with the real estate sector.

Table 7

Annual rates of growth

2000/11

\begin{tabular}{|c|c|}
\hline Year & GDP rate of growth \\
\hline 2000 & $5.00 \%$ \\
\hline 2001 & $3.60 \%$ \\
\hline 2002 & $2.70 \%$ \\
\hline
\end{tabular}




\begin{tabular}{|l|l|}
\hline 2003 & $3.10 \%$ \\
\hline 2004 & $3.30 \%$ \\
\hline 2005 & $3.60 \%$ \\
\hline 2006 & $4.00 \%$ \\
\hline 2007 & $3.60 \%$ \\
\hline 2008 & $0.90 \%$ \\
\hline 2009 & $-3.70 \%$ \\
\hline 2010 & $-0.10 \%$ \\
\hline 2011 & $0.70 \%$ \\
\hline
\end{tabular}

Source: INE

Therefore, the swift deterioration of Spain's public finance flashed warning lights on the capacity of its government to face the services of its increasing public debt, which had exceptionally short maturity structures. Spain was following Ireland's steps with a three-year delay.

\section{ITALY: A DIFFERENT “OLD” DEBTOR}

The Italian government was highly indebted long before the crisis outburst. In 2007 , the general government debt to GDP ratio was already 103.1, second only to Greece, and well above the $60 \%$ Maastrict criterion. However, nobody worried at that time for the Italian public debt and the Italian government had no problem refinancing it. Between 2007 and 2010, it only increased 15\%.

However, the American financial crisis deeply affected the Italian economy. The transmission mechanism was the contraction in the interbank loan market that was the immediate consequence of the crisis. Banks refused to lend money to each other because of a lack of liquidity and the uncertainty about the financial soundness of borrowers. Besides the contraction in liquidity, Italian banks were also affected by their close links with central and eastern European countries where they had built a network of branches and affiliated banks. There was a risk of the collapse or illiquidity of this part of the network. The government responded to the risk of banking crisis by guaranteeing bank deposits to a maximum of $€ 103,000$ in the event of a bankruptcy. This avoided a bank run on deposits. However, banks reacted to the liquidity crisis by reducing credit to clients and consumers and raising the amount of collateral required for new loans. These measures affected investment and consumption. Bugamelli et al. $(2009,11)$ estimate that in the period from January 2008 to June 2009 production fell by more than $35 \%$ in sectors such as electrical machinery, metallurgy and cars. The GDP rate of growth became negative in 2008 and 2009 (Table 8). Growth resumed in 2010, but was snuffed out in 2011. 
Table 8

Annual rates of growth

2000/11

\begin{tabular}{|c|c|}
\hline Year & \% \\
\hline 2000 & 3.7 \\
\hline 2001 & 1.9 \\
\hline 2002 & 0.5 \\
\hline 2003 & 0.0 \\
\hline 2004 & 1.7 \\
\hline 2005 & 0.9 \\
\hline 2006 & 2.2 \\
\hline 2007 & 1.7 \\
\hline 2008 & -1.2 \\
\hline 2009 & -5.5 \\
\hline 2010 & 1.8 \\
\hline 2011 & 0.4 \\
\hline
\end{tabular}

Source: Eurostat

The reduction in economic activity cut the amount of tax collected and anticyclical policies increased public expenditure. As a result, there was a significant increase in the public deficit (see Table 9).

Table 9

\section{General government balance}

2000/11

(Percentage of GDP)

\begin{tabular}{|c|c|}
\hline Year & $\%$ \\
\hline 2000 & 0.8 \\
\hline 2001 & -3.1 \\
\hline 2002 & -3.1 \\
\hline 2003 & -3.6 \\
\hline 2004 & -3.5 \\
\hline 2005 & -4.4 \\
\hline
\end{tabular}




\begin{tabular}{|l|l|}
\hline 2006 & -3.4 \\
\hline 2007 & -1.6 \\
\hline 2008 & -2.7 \\
\hline 2009 & -5.4 \\
\hline 2010 & -4.6 \\
\hline 2011 & -3.9 \\
\hline
\end{tabular}

Source: Eurostat

After Berlusconi stepped down, the new Prime Minister Mario Monti launched a deep austerity plan including measures such as increasing the retirement age, raising property taxes, simplifying the operation of government agencies and going after tax evaders.

In contrast to most European countries, the banking system in Italy practically did not resort to any public help between 2008 and 2011. Italian banks mainly faced the crisis by raising funds in capital markets. Italy's banking system required very low support from the ECB (Table 10). The results of the EU-wide stress test carried out by the European Banking Association in 2010 and 2011 show that the included Italian banks successfully passed the test. Moreover, the Italian banking system seems to have low exposure to government debt; it holds less than $10 \%$ of domestic public debt against more than $40 \%$ in the case of Spanish banks - as well as low exposure to foreign sovereign risk, which represents only $23 \%$ of the total government debt Italian banks hold (see Bolton and Jeanne, 2011).

Table 10

Funds provided by the ECB to national banking systems as of December 2011

Percentage of GDP

\begin{tabular}{|c|c|}
\hline Country & \% \\
\hline Ireland & 87.79 \\
\hline Greece & 61.46 \\
\hline Portugal & 27.65 \\
\hline Nederlands & 26.9 \\
\hline Spain & 16.83 \\
\hline Italy & 12.65 \\
\hline France & 10.89 \\
\hline Belgium & 9.54 \\
\hline Austria & 4.5 \\
\hline Germany & 2.16 \\
\hline
\end{tabular}

Source: OECD 
Therefore, in contrast to Spain, Italy's problem seems to be essentially located in its public debt, whose ratio to GDP, although high, is no worse than it was 20 years ago, when nobody worried about it. In fact, the country's debt first hit $120 \%$ of GDP in 1993, after the public deficit reached 9.5\% of GDP in 1992.

After the exchange rate turmoil that hit the European monetary system in 1992, Italy devalued the lira. Italian trade performance improved as import growth slowed, while export growth remained relatively constant. Therefore, Italy went into the eurozone with a large surplus on its trade accounts. The high levels of Italian public debt only became a problem when, in the context of the 2011/12 European economic climate, the private sector began to lose confidence in the ability of the Italian state to service its debt.

\section{SUMMARY AND CONCLUSIONS}

The European indebtedness process does not accept a unique explanation. Of course, it may be argued that the European as well as the American crises are just chapters in a global credit bubble (McKinsey Global Institute, 2011) or the consequences of a global money or savings glut. However, this explains little except that Europeans and Americans have had access to cheap money during the past 10 years.

This paper shows that among the most indebted European countries there are at least two different groups. One made up of "old" debtors, whose debt to GDP ratios slightly grew between 2001 and 2007. This means that in these countries the debt problem antecedes the introduction of the euro. A second group of "new" debtors comprises those countries whose debt suddenly increased as a result of the 2007/08 financial crisis. These are the cases of Ireland and Iceland.

Spain is a special case whose debt to GDP ratio was substantially lower than the weight of the debt of the United Kingdom and Germany not to mention Greece or Italy. However, its public debt was severely punished by the market because of the doubts about its banking system's health, which raised suspicion that it might require governmental support, as in the cases of Ireland and Iceland.

Therefore, although it is true that the US financial crisis triggered the European debt crisis, it did it through different channels. In the cases of Ireland and Iceland, through a severe credit squeeze and a reduction in banks' abilities to access the capital markets. The drain of liquidity experienced by the banking system precipitated governmental intervention with the consequential jump in public debt. However, in the cases of Greece, Italy and Portugal, the American financial crisis mainly brought attention upon the fiscal situation of countries already heavily indebted, who could face growing difficulties to roll over their debts in an increasing climate of fear and distrust.

Far from helping to reverse their pre-existing fiscal imbalances, entrance into the euro-zone had aggravated them for Greece and Portugal. In fact, the continuous revaluation of the euro worsened their budget imbalances after 2000, increasing their public debt. A positive association between the rate of exchange and budget imbalance was found for both countries. After the debt crisis burst, both countries found themselves without access to capital markets and had to resort to IMF/EU bailout packages in an attempt to stabilize their public finances. 
In 2007, Italy's general government debt to GDP ratio was 103.1, second only to Greece, and well above the $60 \%$ Maastricht criterion. However, nobody worried at that time for the Italian public debt and the Italian government had no problem in refinancing it. Moreover, it only increased 15\% between 2007 and 2010. Therefore, the Italian debt crisis is a clear example of the change in humor in financial markets after the American financial crisis.

The announcement by the President of the ECB, in mid-2012, that the ECB would become the euro-zone's lender of last resort by starting to purchase the sovereign bonds of the area's stricken economies calmed the waters, allowing European authorities to buy time to figure out how they could get the area out of the debt crisis. On top of this, a new European Stability Mechanism was created to replace the European Financial Stability Facility and the European Financial Stabilization Mechanism. This offered bank recapitalization packages directly to the financial sector, rather than doing so via national treasuries as in the past with existing EU funding programs. In parallel, a Single Supervisory Mechanism was established for the oversight of credit institutions.

However, as stated above, what has not been done before in the form of resource transfers from the richer to the poorer countries of the euro-zone has to be done now in the way of helping these countries restructure their debts. There is no other way out of the crisis.

\section{REFERENCES}

Abell, J.D. (1990):'Twin Deficits During the 1980's: An Empirical Investigation", Journal of Macroeconomics, 12, 81-96.

Alesina A, and Tabellini G. 1990. A positive theory of fiscal deficits and government debt. Rev.Econ. Stud.,57, 403-14.

Alkswani, M. (2000).The Twin Deficits Phenomenon in Petroleum Economy: Evidence from Saudi Arabia. Paper presented at the seventh annual conference, economic research forum (ERF).http://www.erf.org.eg/CMS/uploads/pdf/1185358196_finance1.pdf

André, C. (2010). A Bird's Eye View of OECD Housing Markets.OECD

Economics Department Working Papers, No. 746, OECD Publishing.http://www.cchpr.landecon.cam.ac.uk/Conference2010/Downloads/Papers/P1 enary/Andre\%20C\%20Paper.pdf

Arellano, M. and Bentolila, S. (2009). La burbuja inmobiliaria: causas y responsables. In La Crisis de la Economía Española: Lecciones y Propuestas, FEDEA, 28-31. http://www.crisis09.es/PDF/la-crisis-de-la-economia-espanola.pdf

Anoruo, E. and Ramchander, S. (1998). Current Account and Fiscal Deficits: Evidence from Five Developing Economies of Asia. Journal of Asian Economics, 9, 487-501.

Beker, V. A. (2008).Trade Liberalization, Inequality and Unemployment: Lessons from the Argentine Case.http://dx.doi.org/10.2139/ssrn.1126402

Beker, V. A. (2010). On the economic crisis and the crisis of economics. Economics Discussion Papers 2010-18.Kiel Institute for the World Economy.http://econstor.eu/bitstream/10419/36658/1/630979766.pdf 
Bianchi, J. (2011). Overborrowing and Systemic Externalities in the Business Cycle. American Economic Review, 101, December, 3400-3426.

Bolton, P. and Jeanne, O. (2011).Sovereign default risk and bank fragility in financially integrated economies.IMF Economic Review, 59, 162-194. http://www.palgrave-journals.com/imfer/journal/v59/n2/abs/imfer20115a.html

Bordo, M. D.,Eichengreen, B., Klingebiel, D. and Martinez-Peria, M. S. (2001). Is the Crisis Problem Growing More Severe? Economic Policy 16, April, 51-82.

Bordo, M. D. and Murshid, A. P. (2001).Are Financial Crises Becoming Increasingly More Contagious? What Is the Historical Evidence?in Forbes, K. and Claessens, S., eds., International Financial Contagion: How It Spreads and How It Can be Stopped, New York, Kluwer Academic Publications, 367-406.

Borio, C. and Disyatat, P. (2011).Global imbalances and the financial crisis: Link or no link? BIS Working Papers No 346.

Bracke, T. and Fidora, M. (2012).The macro-financial factors behind the crisis: Global liquidity glut or global savings glut?The North American Journal of Economics and Finance. Volume 23, Issue 2, August, 185-202.

Bugamelli, M., Cristadoro, R. and Zevi, G. (2009), La crisi internazionale e il sistema produttivoitaliano:un'analisi su dati a livello di impresa, Occasional Papers 58 ,

Banca d'Italia,Rome.http://www.bancaditalia.it/pubblicazioni/econo/quest_ecofin_2/QF_58

Carlin, W. (1998).The new East German economy: problems of transition, unification and institutional mis-match. University College London.http://www.ucl.ac.uk/ uctpa36/East\%20Germany\%203\%20problems.pdf

Cavallo, M. (2005).Government Consumption Expenditures and the Current Account. Federal Reserve Bank of San Francisco.Working Paper 200503.http://www.frbsf.org/publications/economics/papers/2005/wp05-03bk.pdf

Dewald, W.G. and Ulan, M. (1990): The Twin Deficit Illusion. Cato Journal, 10, 689- 707.

Di Quirico, R. (2010). Italy and the Global Economic Crisis. Bulletin of $\begin{array}{lllll}\text { Italian Politics.Vol. } 2, \quad \text { No. } & \text { 2, } & \text { 3-U.URL: }\end{array}$ http://www.gla.ac.uk/media/media_191024_en.pdf

Eichengreen, B., and Lindert, P. H.(1989,), eds. The International Debt Crisis in HistoricalPerspective.Cambridge: MIT Press.

Eichengreen, B. and Park, B. (2012).The World Economy after the Global Crisis. A New Economic Order for the 21st Century. World Scientific Studies in International Economics

Éltetö, A.(2011). Portugal and Spain: causes and Effects of the crisis. Baltic Journal of European Studies, vol.1 no. 2, September, 34/48.http://www.ies.ee/iesp/No10/bjes_no10.pdf\#page=34

Enders, W. and Lee, B.S. (1990):" Current Account and Budget Deficits: Twins or Distant Cousins?". The Review of Economics and Statistics.72, 373-81.

Erceg, C. and Guerrieri, L.(2005). Expansionary Fiscal Shocks and the Trade Deficit, Computing in Economics and Finance, Society for Computational Economics.

Farhi, E. and Tirole, J. Collective moral hazard, maturity mismatch and systemic bailouts. N.B.E.R. Working Paper 15138.www.nber.org/papers/w15138

Farhi, E. and andTirole, J. (2009).Collective MoralHazard, Maturity Mismatch and Systemic Bailouts. Toulouse School of Economics Working Paper.http://www.tse-fr.eu/images/doc/wp/ng/wp_nogroup_52_2009.pdf

Feldstein, M. (2012).The Failure of the Euro.Foreign Affairs, JanuaryFebruary. http://www.foreignaffairs.com/articles/136752/martin-feldstein/the-failure-ofthe-euro 
Frenkel, R. (2012). Lessons from a comparative analysis of financial crises. INFER Workshop on The Euro: manage it or leave it! Faculty of Economics, Gabriele d'Annunzio University, Pescara, June 22-23.

Frenkel, R. (2013). What have the crises in emerging markets and the Euro zone in common and what differentiate them?. http://www.itf.org.ar/pdf/lecturas/lectura67.pdf

Georgantopoulos, A. G. and Tsamis, A. (2011).The Macroeconomic Effects of Budget Deficits in Greece: A VAR-VECM Approach. International Research Journal of Finance and Economics. Issue 79, Decermber, pp. 156-166.

Gianviti, F., Krueger, A., Pisani-Ferry, J., Sapir, A. and von Hagen, J. (2010). A European Mechanism for Sovereign Debt Crisis Resolution: A Proposal. Bruegel.http://aei.pitt.edu/15123/1/101109_BP_Debt_resolution_BP_clean_01.pdf

Goldstein, M., G. Kaminsky and C. Reinhart (1999), Assessing Vulnerability. Institute for International Finance, Washington, D.C. http://mpra.ub.unimuenchen.de/13629/

Governor of the Central Bank of Ireland (2010).The Irish Banking Crisis Regulatory and Financial Stability Policy 20032008.http://www.financialregulator.ie/pressarea/pressreleases/Pages/TheIrishBankingCrisis,RegulatoryandFinancialStabilityPolicy2 003\%E2\%80\%932008.aspx

Islam, M. F. (1998). "Brazil's Twin Deficits: An Empirical Examination." Atlantic Economic Journal, no. 2, pp. 121-28.

Katsimi, M. and Moutos, T. (2010). "EMU and the Greek Crisis," European Journal of Political Economy, December, 26(4), 568-576.

Khalid, A.M and Teo, W.G. (1999) "Causality Tests of Budget and Current Account Deficits: Cross-Country Comparisons” Empirical Economics, 24, 389-402.

Kim.K.H. (1995): On the Long-run Determinants of the US Trade Balance: A Comment. Journal of Post Keynesian Economics.17, 447-55.

Lane, P.R.(2010).The Irish Crisis. IIIS Discussion Paper No.356.http://www.tcd.ie/iiis/documents/discussion/pdfs/iiisdp356.pdf

Lapavitsas, K. (2012). Crisis in the Eurozone. Verso, London.

Leachman, L. L. and Francis, B. 2002.Twin Deficits: Apparition or Reality? Applied Economics, Vol. 34, p. 1121-32.

Manganelli, S. and Wolswijk, G. (2007).Market discipline, financial integration and fiscal rules: what drives spreads in the euro area government bond market? Working Paper Series 745, European Central Bank.http://www.ecb.europa.eu/pub/pdf/scpwps/ecbwp745.pdf

McKinsey Global Institute (2011).Debt and deleveraging: The global credit bubble and its economic consequences (Updated Analysis). http://www.mckinsey.com/insights/mgi/research/financial_markets/debt_and_deleveragi ng the global_credit_bubble_update

Miller, S.M. and Russek, F.S. (1989): "Are the Twin Deficits Really Related?" Contemporary Policy Issues. 7, 91-115.

Milne, A. (2013). Register, Cap and Trade: A Proposal for Containing Systemic Liquidity Risk. Economics: The Open-Access, Open-Assessment E-Journal, Vol. 7, 2013-7. http://dx.doi.org/10.5018/economics-ejournal.ja.2013-7

Minsky, H. P.(1992). The Financial Instability Hypothesis. The Jerome Levy Economics Institute of Bard College. Working Paper No.

74.http://www.levyinstitute.org/pubs/wp74.pdf 
Miranda, M. S. and Calvo Hornero, A. Evolution of the Spanish and Italian Banking in the Financial World Crisis. http://xivrem.ujaen.es/wpcontent/uploads/2012/05/14-R-040M403.pdf

Mukhtar, T., Zakaria, M., and Ahmed, M. (2007). An empirical investigation for the twin deficits in Pakistan.Journal of Economic Cooperation, 28,4, 63-80.

Pagano, M. and vonThadden, E. L. (2004). The European Bond Markets under EMU. Oxford Review of Economic Policy, Oxford University Press, vol. 20(4), 531-554, Winter.

Paniza, U. (2013). Do We Need a Mechanism for Solving Sovereign Debt Crises? A Rule-Based Discussion. Graduate Institute of International and Development $\begin{array}{llll}\text { Studies } & \text { Working } & \text { Paper } & \text { No: }\end{array}$ http://repec.graduateinstitute.ch/pdfs/Working papers/HEIDWP03-2013.pdf

Pérez-Caldentey, E. and Vernengo, M. (2012).The Euro Imbalances and Financial Deregulation: A Post-Keynesian Interpretation of the European Debt Crisis. Levy Economics Institute of Bard College Working Paper No. 702.http://www.levyinstitute.org/pubs/wp 702.pdf

Piersanti, G., (2000). Current account dynamics and expected future budget deficits: some international evidence. Journal of International Money and Finance, Elsevier, vol. 19(2), 255-271, April.

Reinhart, C.M. and Rogoff, K.S. (2004) Serial Default and the "Paradox" of Rich to Poor Capital Flows.National Bureau of Economic Research. Working Paper 10296.http://www.nber.org/papers/w10296

Reinhart, C. M., and Kenneth S. Rogoff. K. S. (2008a). Banking Crises: An Equal Opportunity Menace. National Bureau of Economic Research Working Paper 14587.

Reinhart, Carmen M., and Kenneth S. Rogoff. 2008b. This Time is Different: A Panoramic View of Eight Centuries of Financial Crises. NBER Working Paper No. 13882

Reinhart, C. M., Rogoff, K. S. and Savastano, M. A. (2003).Debt Intolerance. Brookings Papers on Economic Activity, Vol.1, Spring, 1-74.

Roubini, N. (2001). Debt Sustainability: How to Assess Whether a Country is Insolvent. Stern School of Business, New York University.http://people.stern.nyu.edu/nroubini/papers/debtsustainability.pdf

Schich, S. (2008).Challenges Related to Financial Guarantee Insurance.

Financial Market Trends, OECD, 81-113.

Schneider and Kirchgässner (2009).Financial and world economic crisis: What did economists contribute? Public Choice. Springer. Vol. 140(3), September, 319327.

Sturzenegger, F. and Zettlemeyer, J. (2006). Debt Defaults and Lessons from aDecade of Crises Cambridge: MIT Press.

Tichy, G. (2011)). Could we have foreseen the financial crisis? In Streissler, E. andTichy, G., eds., How to Forecast Economic Developments During and After Crises. Austrian Academy of Sciences, Vienna.

Tomz, M. and Wright, M.L. J. (2007) Do Countries Default in "Bad Times"? Journal of the European Economic Association, 5(2-3), April-May, 352-60.

Véron, N. (20112). Financial Reform after the Crisis, in Eichengreen and Park (Eds.), The World Economy after the Global Crisis. A New Economic Order for the 21st Century. World Scientific Studies in International Economics. Chapter. 2. 